\title{
Endogenous Interleukin-4 Downregulates the Type 1 CD4 T Cell-Mediated Immune Response Induced by Intramuscular DNA Immunization
}

\author{
MAURICIO M. RODRIGUES, ${ }^{1}$ MILENA B.P. SOARES, ${ }^{2}$ and JOSÉ RONNIE C. VASCONCELOS ${ }^{1}$
}

\begin{abstract}
Intramuscular (i.m.) administration of eukaryotic plasmid vectors containing foreign genes is a general immunization strategy capable of inducing protective type 1 immune responses against viral, bacterial, fungal, and parasitic infections. We have described that immunization with a plasmid containing a gene encoding a parasite antigen elicits specific type 1 protective immune responses against experimental infection with the human protozoan parasite Trypanosoma cruzi. However, we had evidence suggesting that DNA immunization concomitantly activated specific type 2 immune responses. To determine precisely the influence of the type 2 cytokine interleukin-4 (IL-4) during DNA immunization, we compared the immune responses of genetically modified IL-4-deficient or wild-type (wt) BALB/c mice. IL-4-deficient mice had a significantly lower ratio of specific serum IgG1/IgG2a, and on in vitro restimulation with antigen, their spleen cells secreted significantly higher amounts of interferon- $\gamma($ IFN- $\gamma$ ). In contrast, absence of IL-4 did not affect total serum antibody response, $\mathrm{T}$ cell proliferative responses, or activation of IFN- $\gamma$-producing $\mathrm{CD8}^{+} \mathrm{T}$ cells. Our results suggested that in contrast to conventional adjuvants, such as alum and complete Freund's adjuvant, specific IgG1 in DNA-immunized BALB/c mice was highly dependent on IL-4. To our knowledge, our study provides the first evidence that endogenous IL-4 selectively downregulates the type $1 \mathrm{CD4}^{+} \mathrm{T}$ cell-mediated immune response induced by i.m. genetic immunization, a fact that may have implications for the design of certain DNA vaccines.
\end{abstract}

D NA IMMUNIZATION WITH PLASMIDS containing foreign genes can be used successfully to elicit immune responses to viral, bacterial, fungal, and parasitic antigens. This type of immunization has a series of advantages over other strategies because it is relatively simple and generates long-lived immune responses mediated by MHC class I and class II-restricted T cells. In addition, genetic vaccination has the advantage of inducing predominantly type 1 immune responses. ${ }^{(1)}$

We have performed detailed studies on the immunogenic properties of a plasmid encoding an antigen expressed on the surface of infective forms of Trypanosoma cruzi. This protozoan parasite causes Chagas' disease, an acute and chronic illness that afflicts 16-18 million people in Latin America. Initially, we reported that intramuscular (i.m.) immunization of $\mathrm{BALB} / \mathrm{c}$ mice with plasmid p154/13, which contains the gene encoding the catalytic domain of $T$. cruzi trans-sialidase (TS), elicited remarkable protective immunity against lethal infection with $T$. cruzi. $^{(2)}$ A detailed characterization of the immune re- sponses generated by vaccination with p154/13 revealed that bulk cells from DNA-immunized mice had $\mathrm{CD}^{+}{ }^{+}$and $\mathrm{CD} 8^{+}$ $\mathrm{T}$ cells that produced interferon- $\gamma(\mathrm{IFN}-\gamma)$ but not interleukin4 (IL-4) or IL-10. The TS-specific T cells were characterized at the clonal level. From DNA-vaccinated mice, we obtained cytotoxic type $1 \mathrm{CD}^{+}$or $\mathrm{CD}^{+} \mathrm{T}$ cell clones that displayed remarkable antiparasitic activities in vitro. ${ }^{(3,4)}$

Unexpectedly, we also collected evidence suggesting that immunization with p154/13 activated specific type $2 \mathrm{CD}^{+}{ }^{+} \mathrm{T}$ cells. The first evidence was indirect and relied on the presence of specific IgG1 in the sera of immunized mice. ${ }^{(1)}$ This evidence was corroborated by the fact that we isolated antigenspecific type $2 \mathrm{CD}^{+} \mathrm{T}$ cell clones from DNA-immunized mice. ${ }^{(3,4)}$

IL-4 has an important role in the generation of type 2 immune responses. ${ }^{(5)}$ To date, to our knowledge, no studies are available on the precise participation of IL-4 in the immune responses induced by genetic vaccination. To address this ques-

\footnotetext{
${ }^{1}$ Departamento de Microbiologia, Imunologia e Parasitologia, Universidade Federal de São Paulo-Escola Paulista de Medicina, São Paulo, SP, Brazil, 04023-062.

${ }^{2}$ Centro de Pesquisas Gonçalo Moniz, Fundação Oswaldo Cruz, Salvador, BA, Brazil 40295-001.
} 
Table 1. Antibody Immune Response of IL-4 ${ }^{+/+}$and IL-4 ${ }^{-/-}$BALB/c Mice Immunized with p154/13

\begin{tabular}{|c|c|c|c|c|c|}
\hline \multirow{2}{*}{$\begin{array}{l}\text { Mouse } \\
\text { strain }\end{array}$} & \multirow[b]{2}{*}{ Immunogen $^{\mathrm{a}}$} & \multirow{2}{*}{$\begin{array}{l}\text { Antibody } \\
\text { titers }^{\mathrm{b}}(\log )\end{array}$} & \multicolumn{3}{|c|}{$\begin{array}{c}\text { IgG subclasses } \\
\text { antibody titers }{ }^{\mathrm{b}}(\log )\end{array}$} \\
\hline & & & $\operatorname{Ig} G 1$ & $\operatorname{Ig} G 2 a$ & $\operatorname{Ig} G 2 b$ \\
\hline \multirow[t]{2}{*}{$\mathrm{IL}-4^{+/+}$} & pcDNA3 & $<2.00$ & $\mathrm{NT}^{\mathrm{c}}$ & NT & NT \\
\hline & p154/13 & $5.72 \pm 0.33^{\mathrm{d}}$ & $5.56 \pm 0.12^{\mathrm{e}}$ & $4.5 \pm 0.24^{\mathrm{e}}$ & $4.15 \pm 0.35^{\mathrm{d}}$ \\
\hline \multirow[t]{2}{*}{ IL-4 ${ }^{-/-}$} & pcDNA3 & $<2.00$ & NT & NT & $\mathrm{NT}$ \\
\hline & p154/13 & $5.61 \pm 0.30^{d}$ & $3.8 \pm 0.62^{\mathrm{e}}$ & $5.16 \pm 0.16^{\mathrm{e}}$ & $4.35 \pm 0.12^{\mathrm{d}}$ \\
\hline
\end{tabular}

${ }^{a} \mathrm{IL}-4^{+/+}$or IL-4 ${ }^{-/-}$BALB/c mice were immunized i.m. with three doses of plasmid p154/13 or pcDNA3. Each dose consisted of $100 \mu \mathrm{g}$ plasmid administered at 3-week intervals.

${ }^{b}$ Fourteen days after the last immunization, blood samples were collected, and each individual serum sample was assayed in serial dilutions for the presence of antibodies to recombinant TS by ELISA. The individual titers were considered as the highest dilution of serum that presented an OD at $492 \mathrm{~nm}>0.1$. Results represent the mean value obtained for 9 mice \pm SD of the mean.

${ }^{\mathrm{c}} \mathrm{NT}$, not tested.

${ }^{\mathrm{d}}$ The results obtained for groups of IL-4 ${ }^{+/+}$and IL- $4^{-/-}$mice immunized with p154/13 were compared by Student's $t$-test. The difference between them was not statistically significant $(p>0.05)$.

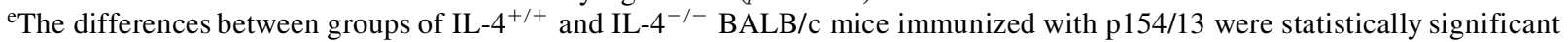
by the Student's $t$-test. IgG1, $p<0.0001 ; \operatorname{IgG} 2 \mathrm{a}, p=0.0006$.

tion, we compared the immune responses elicited by DNA vaccination with p154/13 in wild-type (wt) and IL-4-deficient $\mathrm{BALB} / \mathrm{c}$ mice.

Female 5-to-8-week-old wt $\left(\mathrm{IL}-4^{+/+}\right)$or genetically modified IL-4-deficient (IL-4 ${ }^{-/-(6)}$ ) BALB/c mice were kindly provided by the department of immunology of the University of São Paulo.

Purification and i.m. immunization with plasmid p154/13 were carried out exactly as described earlier. ${ }^{(2,3)}$ Production of the recombinant TS protein and detection of specific serum antibodies were achieved as previously described. ${ }^{(2,3)}$ ELISA for the detection of mouse IgG subclasses was performed with peroxidase-labeled secondary antibodies specific for mouse IgG1, $\mathrm{IgG} 2 \mathrm{a}$, and IgG2b (all obtained from ICN Biochemicals, Irvine, CA) diluted 1:1000.

Two to five weeks after the third and last dose of plasmid, spleens from DNA-immunized BALB/c mice (3 animals per group) were removed to prepare splenocyte suspensions used in the different immunologic assays. The $\mathrm{T}$ cell proliferation assay and determination of IFN- $\gamma$ secretion by spleen cells stimulated with A20J cells coated with the TS peptide IYNVGQVSI were performed as described earlier. ${ }^{(3,7)}$ For IFN- $\gamma$ determination, $4 \times 10^{6}$ spleen cells were cultivated in triplicate in flatbottom 96-well plates in a final volume of $200 \mu$ l. The recombinant protein was added to the cultures at a final concentration of $10 \mu \mathrm{g} / \mathrm{ml}$. After 5 days, the supernatants were collected for cytokine determination. IFN- $\gamma$ was estimated by capture ELISA using antibodies and recombinant cytokines purchased from PharMingen (San Diego, CA). ${ }^{(3,7)}$ The number of IFN- $\gamma$-secreting cells specific for the peptide IYNVGQVSI was determined by the ELISPOT assay, as originally described. ${ }^{(8,9)}$

Antibody titers similar to those of recombinant TS were detected in the sera of $\mathrm{IL}-4^{+/+}$and IL- $4^{-/-}$mice immunized with p154/13 (Table 1). When antibody titers were compared after each plasmid immunization, no significant differences were observed between them (data not shown). Control mice of both

Table 2. IFN- $\gamma$ Secretion by Spleen Cells from IL-4 ${ }^{+/+}$and IL-4 ${ }^{-/-}$BALB/c Mice Immunized with p154/13

\begin{tabular}{|c|c|c|c|c|}
\hline \multirow{2}{*}{$\begin{array}{l}\text { Mouse } \\
\text { strain }\end{array}$} & \multirow[b]{2}{*}{ Immunogen $^{\mathrm{a}}$} & \multirow{2}{*}{$\begin{array}{l}\text { Number of } \\
\text { experiments }\end{array}$} & \multicolumn{2}{|c|}{$\begin{array}{l}\text { IFN- } \gamma \text { concentration } \\
\text { median ng/ml (range) }\end{array}$} \\
\hline & & & No antigen & Recombinant $T S^{\mathrm{b}}$ \\
\hline \multirow[t]{2}{*}{$\mathrm{IL}-4^{+/+}$} & pcDNA3 & 2 & $<0.2$ & $<0.2$ \\
\hline & p154/13 & 5 & $<0.2$ & $2.0(1.8-2.7)^{\mathrm{c}}$ \\
\hline \multirow[t]{2}{*}{ IL-4 ${ }^{-/-}$} & pcDNA3 & 2 & $<0.2$ & $<0.2$ \\
\hline & p154/13 & 5 & $<0.2$ & $9.8(4.8-12.8)^{\mathrm{c}}$ \\
\hline
\end{tabular}

${ }^{a} \mathrm{IL}-4^{+/+}$and IL-4 ${ }^{-/-}$BALB/c mice were immunized as described in Table 1 . Two to five weeks after the last immunization, pooled spleen cells were collected from 3 mice immunized with the indicated plasmid.

${ }^{\mathrm{b}}$ Spleen cells $\left(2 \times 10^{7} / \mathrm{ml}\right)$ were stimulated in vitro with $10 \mu \mathrm{g} / \mathrm{ml}$ recombinant TS protein. After 5 days in culture, the supernatants were collected, and the concentration of IFN- $\gamma$ was estimated. Results are expressed as median of the indicated number of experiments.

${ }^{\mathrm{c}}$ The results obtained for groups of IL- $4^{+/+}$and IL-4 ${ }^{-/-}$mice were immunized with p154/13 were compared statistically using the Mann-Whitney test. The difference between them was significant $(p=0.006)$. 
Table 3. CD4 Dependence of IFN- $\gamma$ Secretion by Spleen Cells from IL-4 $4^{+/+}$ AND IL-4 $4^{-/-}$BALB/c Mice IMMUNIZED with p154/13

\begin{tabular}{|c|c|c|c|c|c|c|}
\hline \multirow{2}{*}{$\begin{array}{l}\text { Mouse } \\
\text { strain }^{\mathrm{a}}\end{array}$} & \multirow{2}{*}{$\begin{array}{c}\text { Experimental } \\
\text { group } \\
\text { no. }\end{array}$} & \multirow{2}{*}{$\begin{array}{c}\text { No } \\
\text { antigen }\end{array}$} & \multicolumn{4}{|c|}{$\begin{array}{c}\text { IFN- } \gamma \text { concentration }(\mathrm{ng} / \mathrm{ml})^{\mathrm{b}} \\
\text { Recombinant } T S\end{array}$} \\
\hline & & & Rat $\operatorname{Ig} G$ & $\alpha C D 4$ & $\alpha C D 8$ & $\alpha C D 4+\alpha C D 8$ \\
\hline \multirow[t]{2}{*}{$\mathrm{IL}-4^{+/+}$} & 1 & $<0.2$ & $1.7 \pm 0.2$ & $0.3 \pm 0.1$ & $1.3 \pm 0.1$ & $0.3 \pm 0.1$ \\
\hline & 2 & $<0.2$ & $1.5 \pm 0.1$ & $0.1 \pm 0.0$ & $1.5 \pm 0.1$ & $0.2 \pm 0.0$ \\
\hline \multirow[t]{2}{*}{ IL-4 ${ }^{-/-}$} & 1 & $<0.2$ & $4.9 \pm 0.2$ & $<0.2$ & $5.4 \pm 0.4$ & $<0.2$ \\
\hline & 2 & $<0.2$ & $6.0 \pm 0.2$ & $0.4 \pm 0.1$ & $6.1 \pm 0.2$ & $0.5 \pm 0.1$ \\
\hline
\end{tabular}

${ }^{a} \mathrm{IL}-4^{+/+}$or IL-4 ${ }^{-/-}$BALB/c mice were immunized with plasmid p154/13 as described in Table 1.

${ }^{\mathrm{b}}$ For IFN- $\gamma$ detection, spleen cells were stimulated in vitro with $10 \mu \mathrm{g} / \mathrm{ml}$ recombinant TS in the presence of $10 \mu \mathrm{g} / \mathrm{ml} \mathrm{rat} \mathrm{IgG}$ or mAb $\alpha \mathrm{CD} 4, \alpha \mathrm{CD} 8$, or $\alpha \mathrm{CD} 4+\alpha \mathrm{CD} 8$. Results are expressed as average of triplicate cultures \pm SD.

strains immunized with pcDNA3 did not present specific antibodies.

A significant difference between IL- $4^{+/+}$and IL- $4^{-1-}$ mice immunized with p154/13 was detected when the titers of specific antibodies of the different IgG subclasses were estimated. As noted earlier, IL-4 ${ }^{+/+}$mice showed a predominance of specific IgG1. In contrast, IL-4 ${ }^{-1-}$ mice had significantly lower titers of specific antibodies of this IgG subclass and higher titers of IgG2a (Table 1). The IgG1/IgG2a ratio changed dramatically from 10.35 in $\mathrm{IL}-4^{+/+}$mice to 0.09 in $\mathrm{IL}-4^{-/-}$mice.

The presence of IFN- $\gamma$ in supernatants of spleen cells from

FIG. 1. IFN- $\gamma$ secretion by spleen cells specific for peptide IYNVGQVSI of IL- $4^{+/+}$or IL- $4^{-/-}$BALB/c mice immunized with $\mathrm{p} 154 / 13$. Mice were immunized as described in Table 1. (A) Two to five weeks after the last immunization, pooled spleen cells obtained from 3 mice were expanded for 6 days in the presence of irradiated A20J-TS cells. ${ }^{(3,7)}$ The cells were then washed, and the indicated number of cells were restimulated in cultures containing $10^{5}$ irradiated A20J cells pulsed with $1 \mu \mathrm{M}$ peptide IYNVGQVSI. IFN- $\gamma$ was estimated in supernatants collected after $18 \mathrm{~h}$. Results are expressed as average of triplicate cultures \pm SD. This experiment was reproduced three times, with similar results. (B) The ELISPOT assay was performed by adding $5 \times 10^{5}$ spleen cells from each individual mouse per well. To each well, we added $10^{5}$ irradiated A20J cells pulsed or not with $1 \mu \mathrm{M}$ peptide IYNVGQVSI. After $24 \mathrm{~h}$, the cells were removed, and the ELISPOT assay was carried out as described earlier. ${ }^{(8,9)}$ Each circle represents the result of averages of triplicate cultures of spleen cells from a single mouse. Bars represent the averages of 4 mice. When the results obtained for IL- $4^{+/+}$and IL-4 $4^{-I-}$ mice immunized with p154/13 were compared by the Mann-Whitney test, the difference between them was not statistically significant $(p>0.05)$.
DNA-immunized mice was determined after in vitro restimulation with recombinant TS. In five independent experiments, the median concentration of IFN- $\gamma$ in the supernatant of cells obtained from IL-4 ${ }^{-1-}$ mice immunized with $\mathrm{p} 154 / 13$ was significantly higher than that in cultures of cells from IL-4 ${ }^{+/+}$ mice injected with $\mathrm{p} 154 / 13$ ( $p=0.006$, Mann-Whitney test) (Table 2).

IFN- $\gamma$ secretion was dependent on the activation of $\mathrm{CD}^{+}{ }^{+} \mathrm{T}$ cells, as the addition of the monoclonal antibody (mAb) $\alpha \mathrm{CD} 4$ (GK1.5) drastically reduced its concentration in the supernatant of spleen cells stimulated with the antigen. In contrast, under
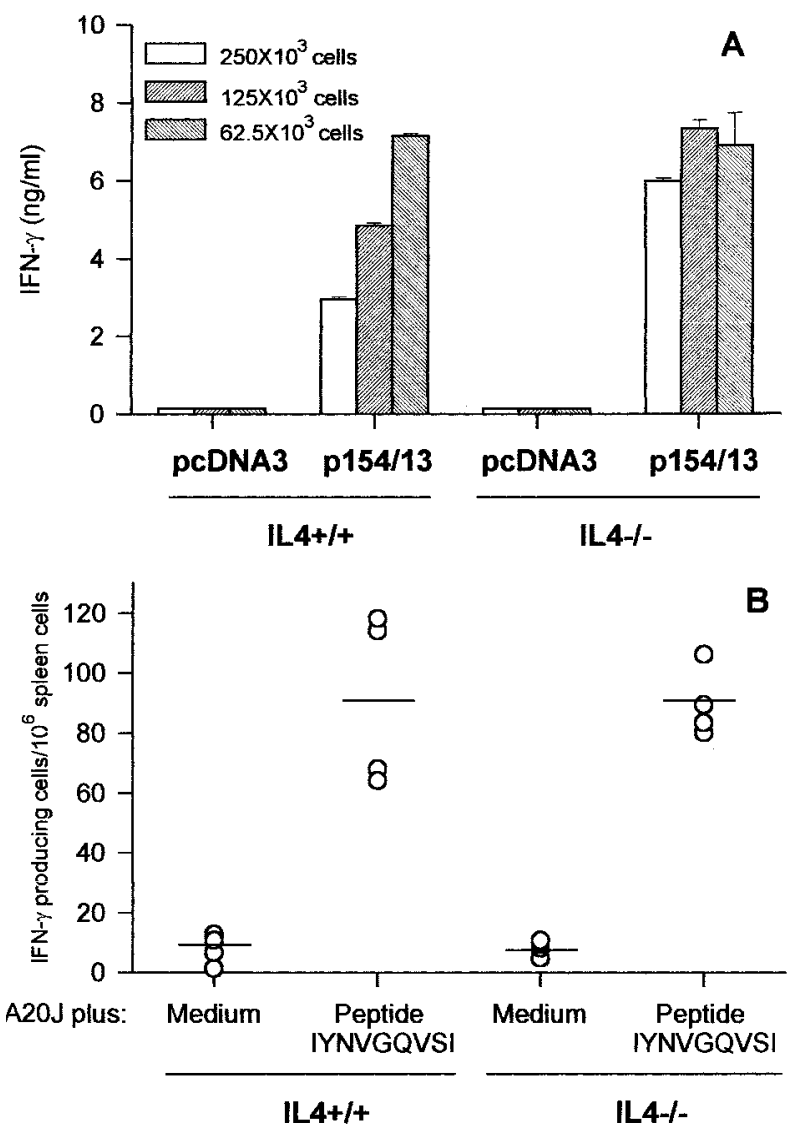
the same circumstances, the addition of mAb $\alpha \mathrm{CD} 8$ (clone 2.43) had little or no impact on IFN- $\gamma$ secretion by specific spleen cells (Table 3 ).

IFN- $\gamma$ secretion by $\mathrm{CD}^{+}$spleen cells from DNA-immunized mice was evaluated after in vitro restimulation with $\mathrm{A} 20 \mathrm{~J}$ cells coated with peptide IYNVGQVSI. ${ }^{(3,7)}$ This peptide has been shown previously to be a $\mathrm{CD} 8^{+} \mathrm{T}$ cell epitope ${ }^{(3)} \mathrm{We}$ found that in the presence of peptide IYNVGQVSI, cells from IL$4^{+/+}$and IL-4 ${ }^{-1-}$ mice immunized with $\mathrm{p} 154 / 13$ secreted comparable amounts of IFN- $\gamma$ (Fig. 1A). These results were further confirmed by the direct ELISPOT assay. The number of cells (per $10^{6}$ spleen cells) that secreted IFN- $\gamma$ in the presence of peptide IYNVGQVSI was similar in IL- $4^{+/+}$and IL- $4^{-1-}$ mice immunized with p154/13 (Fig. 1B). Control mice immunized with pcDNA3 did not present IFN- $\gamma$-secreting cells in the presence of peptide IYNVGQVSI (data not shown).

The present study addressed the question of whether endogenous IL-4 influenced the immune responses elicited by genetic vaccination with a plasmid harboring a parasite gene. The absence of IL-4 did not influence total serum antibody response, $\mathrm{T}$ cell proliferative responses (data not shown), or activation of IFN- $\gamma$-producing $\mathrm{CD}^{+} \mathrm{T}$ cells specific for the peptide IYNVGQVSI. Conversely, IL-4 ${ }^{-1-}$ BALB/c mice had significantly lower titers of specific serum IgG1, accompanied by a significant increase in specific IgG2a. Also important was the observation that on in vitro restimulation with recombinant antigen, spleen cells from IL-4 $4^{-/-}$mice secreted significantly higher amounts of IFN- $\gamma$ compared with cells from IL- $4^{+/+}$mice.

Our results confirm our initial hypothesis that vaccination of BALB/c mice with p154/13 concomitantly activates type 1 and type 2 immune responses. The presence of mixed type 1 and 2 immune responses had been noticed also in mice vaccinated i.m. with plasmids containing genes expressed in a variety of microorganisms (viruses, bacteria, fungi, and parasites) and tumor cells..$^{(10-20)}$ However, the role of IL-4 as a mediator of this type of immune response was not addressed in most of these studies.

In a single study, the predominance of IgG1 observed after genetic immunization with a plasmid expressing a secreted form of the influenza virus hemagglutinin was studied in $\mathrm{IL}_{-} 4^{-1-}$ $\mathrm{BALB} / \mathrm{c}$ mice. Similar to our observation, the ratio of specific serum IgG1/IgG2a antibodies changed from 15 in $\mathrm{IL}_{-} 4^{+/+}$mice to 0.4 in IL- $4^{-1-}$ mice. However, in contrast to our results, the authors reported that the overall antibody titers were lower in IL-4 ${ }^{-1-}$ BALB/c mice. ${ }^{(11)}$

Few earlier publications addressed the participation of IL-4 and its receptor in the control of specific IgG1 generated after immunization with conventional adjuvants, such as alum and complete Freund's adjuvant. In these studies, the reduction of specific IgG1 in BALB/c IL-4 ${ }^{-1-}$ mice was not as dramatic as we describe herein..$^{(21,2)}$ These results led to the proposition that the type 2 immune response induced in the presence of alum was at least in part independent of IL-4 and its receptor. ${ }^{(22)}$ Nevertheless, in the case of immunizations performed in the presence of alum, the absence of IL-4 led to a significant increase in the titers of IgG $2 \mathrm{a}$ and in IFN- $\gamma$ productionby spleen cells. ${ }^{(21,22)}$ Therefore, similar to the observations described here, IL-4 downregulates adjuvant-assistedtype 1 CD4 immune responses.

A possible participation for IL-13 in the switch of specific
IgG1 seems very limited because the average IgG1 titer in IL- $4^{-1-}$ mice is reduced to only $1.75 \%$ of the average titer found in IL- $4^{+/+}$mice (Table 1). Whether IL-13 interferes with the activation of Th1 $1 \mathrm{CD}^{+} \mathrm{T}$ cells is unknown at present and remains to be investigated.

An important observation in our study was the fact that in the absence of IL-4, spleen cells secreted larger amounts of IFN- $\gamma$. Although it is well documented that IL-4 can inhibit the in vivo generation of type 1 immune responses, the precise molecular mechanism mediating this event is still a matter of intense study. Evidence indicates that IL-4-mediated activation of Stat6 leads to silencing of IFN- $\gamma$ gene expression, therefore reducing type 1 immune responses. ${ }^{(23)}$ Whether this or another mechanism operates during DNA immunization will require future studies.

The cells responsible for the in vivo production of IL-4 have not been characterized. It is plausible that $\mathrm{CD} 4^{+} \mathrm{T}$ cells specific for TS are at least in part responsible for IL-4 production. This hypothesis is based on the fact that we isolated IL-4-secreting $\mathrm{CD}^{+}{ }^{+} \mathrm{T}$ cell clones from mice immunized with plasmid p154/13. Nevertheless, because IL-4 can be produced in vivo by a variety of cells, direct evidence should be obtained in the future by adoptive transfer of purified cells.

Recent studies have reported that IL-4 may be important for the development of immune responses mediated by $\mathrm{CD} 8^{+} \mathrm{T}$ cells. In these studies, IL-4 $4^{-1-}$ mice have a drastically reduced priming of specific $\mathrm{CD}^{+} \mathrm{T}$ cells..$^{(24,25)}$ The role of IL-4 in $\mathrm{CD}^{+} \mathrm{T}$ cell priming after DNA vaccination has never been directly addressed. We found that after DNA immunization with plasmid p154/13, priming of peptide-specific, IFN- $\gamma$-secreting $\mathrm{CD}^{+} \mathrm{T}$ cells could be achieved in the absence of IL-4. This result indicates either that IL-4 is not important for priming of $\mathrm{CD}^{+} \mathrm{T}$ cells after i.m. DNA vaccination or that other compensatory mechanism may substitute for IL-4 in our system.

Finally, from a practical point of view, it will be important to establish an experimental model that will allow determination of whether the neutralization of IL-4 during priming represents an alternative for the improvement of protective type 1 immune responses elicited by DNA vaccination.

\section{ACKNOWLEDGMENTS}

This work was supported by grants from Fundação de Amparao à Pesquisa do Estado de São Paulo, CNPq, PRONEX, and FINEP (Brazil). M.M.R. and J.R.C.V. are recipients of fellowships from CNPq and FAPESP, respectively.

\section{REFERENCES}

1. GURUNATHAN, S., KLINMAN, D.M., and SEDER, R.A. (2000). DNA vaccines: immunology, application, and optimization. Annu. Rev. Immunol. 18, 927-974.

2. COSTA, F., FRANCHIN, G., PEREIRA-CHIOCCOLA, V.L., RIBEIRAO, M., SCHENKMAN, S., and RODRIGUES, M.M. (1998). Immunization with a plasmid DNA containing the gene of trans-sialidase reduces Trypanosoma cruzi infection in mice. Vaccine 16, 768-774.

3. RODRIGUES, M.M., RIBEIRÃO, M., PEREIRA-CHIOCCOLA, V.L., RENIA, L., and COSTA, F. (1999). Predominance of CD4 
Th1 and CD8 Tc1 cells revealed by characterization of the cellular immune response generated by immunization with a DNA vaccine containing a Trypanosoma cruzi gene. Infect. Immun. 67, 3855-3863.

4. RODRIGUES, M.M., RIBEIRÃO, M., and BOSCARDIN, S.B. (2000). CD4 Th1 but not Th2 clones efficiently activate macrophages to eliminate Trypanosoma cruzi through a nitric oxide dependent mechanism. Immunol. Lett. 73, 43-50.

5. NELMS, K., KEEGAN, A.D., ZAMORANO, J., RYAN, J.J., and PAUL, W.E. (1999). The IL-4 receptor: signaling mechanisms and biologic functions. Annu. Rev. Immunol. 17, 701-738.

6. NOBEN-TRAUTH, N., KOHLER, G., BURKI, K., and LEDERMANN, B. (1996). Efficient targeting of the IL-4 gene in a BALB/c embryonic stem cell line. Transgenic Res. 5, 487-491.

7. FUJIMURA, A.E., KINOSHITA, S.S., PEREIRA-CHIOCCOLA, V.L., and RODRIGUES, M.M. (2001). DNA sequences encoding $\mathrm{CD}^{+}{ }^{+}$and $\mathrm{CD}^{+}{ }^{+}$T-cell epitopes are important for efficient protective immunity induced by DNA vaccination with a Trypanosoma cruzi gene. Infect. Immun. 69, 5477-5486.

8. RODRIGUES, M., LI, S., MURATA, K., RODRIGUEZ, D., RODRIGUEZ, J.R., BACIK, I., BENNINK, J.R., YEWDELL, J.W., GARCIA-SASTRE, A., NUSSENZWEIG, R.S., ESTEBAN, M., PALESE, P., and ZAVALA, F. (1994). Influenza and vaccinia virus expressing malaria CD8 $\mathrm{T}$ and $\mathrm{B}$ cell epitopes: comparison of their immunogenicity and capacity to induce protective immunity against malaria. J. Immunol. 153, 4636-4649.

9. MIYAHIRA, Y., MURATA, K., RODRIGUEZ, D., RODRIGUEZ, J.R., ESTEBAN, M., RODRIGUES, M.M., and ZAVALA, F. (1995). Quantification of antigen specific $\mathrm{CD}^{+} \mathrm{T}$ cell using ELISPOT assay. J. Immunol. Methods 181, 145-154.

10. CHOW, Y.-H., CHIANG, B.-L., LEE, Y.-L., CHI, W.-K., LIU, W.-C., CHEN, Y.-T., and TAO, M.-H. (1998). Development of Th1 and Th2 populations and the nature of immune responses to hepatitis B virus DNA vaccines can be modulated by codelivery of various cytokine genes. J. Immunol. 160, 1320-1329.

11. TORRES, C.A.T., YANG, K., MUSTAFA, F., and ROBINSON, H.L. (2000). DNA immunization: effect of secretion of DNA-expressed hemagglutinins on antibody responses. Vaccine 18, 805-814.

12. HASSETT, D.E., ZHANG, J., SLIFKA, M., and WHITTON, J.L. (2000). Immune responses following neonatal DNA vaccination are long-lived, abundant, and qualitatively similar to those induced by conventional immunization. J. Virol. 74, 2620-2627.

13. VELIKOVSKY, C.A., CASSATARO, J., GIAMBARTOLOMEI, G.H., GOLDBAUM, F.A., ESTEIN, S., BOWDEN, R.A., BRUNO, L., FOSSATI, C.A., and SPITZ, M. (2002). A DNA vaccine encoding lumazine synthase from Brucella abortus induces protective immunity in BALB/c mice. Infect. Immun. 70, 2507-2511.

14. ABUODEH, R.O., SHUBITZ, L.F., SIEGEL, E., SNYDER, S., PENG, T., ORSBORN, K.I., BRUMMER, E., STEVENS, D.A., and GALGIANI, J.N. (1999). Resistance to Coccidioides immitis in mice after immunization with recombinant protein or a DNA vaccine of a proline-rich antigen. Infect. Immun. 67, 2935-2940.

15. MOR, G., KLINMAN, D.M., SHAPIRO, S., HAGIWARA, E., SEDEGAH, M., NORMAN, J.A., HOFFMAN, S.L., and STEINBERG, A.D. (1995). Complexity of the cytokine and antibody response elicited by immunization of mice with Plasmodium yoelii circumsporozoite protein plasmid DNA. J. Immunol. 155, 20392046.

16. VERCAMMEN, M., SCORZA, T., HUYGEN, K., DE BRAKELEER, J., DIET, R., JACOBS, D., SAMAN, E., and VERSCHUEREN, H. (2000). DNA vaccination with genes encoding Toxoplasma gondii antigens GRA1, GRA7, and ROP2 induces partially protective immunity against lethal challenge in mice. Infect. Immun. 68, 38-45.

17. DREW, D.R., LIGHTOWLERS, M., and STRUGNELL, R.A. (2000). Humoral immune responses to DNA vaccines expressing secreted, membrane bound and non-secreted forms of the Taenia ovis $45 \mathrm{~W}$ antigen. Vaccine 18, 2522-2532.

18. TANAKA, M., KANEDA, Y., FUJII, S., YAMANO, T., HASHIMOTO, K., HUANG, S.K., and HOON, D.S. (2002). Induction of a systemic immune response by a polyvalent melanomaassociated antigen DNA vaccine for prevention and treatment of malignant melanoma. Mol. Ther. 5, 291-299.

19. PIECHOCKI, M.P., PILON, S.A., and WEI, W.Z. (2001). Complementary antitumor immunity induced by plasmid DNA encoding secreted and cytoplasmic human ErbB-2. J. Immunol. 167, 3367-3374.

20. DAVIS, H.L., and McCLUSKIE, M.J. (1999). DNA vaccines for viral diseases. Microbes Infect. 1, 7-21.

21. HUI, G.S., and HASHIMOTO, C.N. (1998). Pathways for potentiation of immunogenicity during adjuvant-assisted immunizations with Plasmodium falciparum major merozoite surface protein 1 . Infect. Immun. 66, 5329-5336.

22. BREWER, J.M., CONACHER, M., HUNTER, C.A., MOHRS, M., BROMBACHER, F., and ALEXANDER, J. (1999). Aluminum hydroxide adjuvant initiates strong antigen-specific $\mathrm{Th} 2$ responses in the absence of IL-4- or IL-13-mediated signaling. J. Immunol. 163, 6448-6454.

23. JANKOVIC, D., SHER, A., and YAP, G. (2001). Th1/Th2 effector choice in parasitic infection: decision making by committee. Curr. Opin. Immunol. 13, 403-409.

24. SCHULER, T., KAMMERTOENS, T., PREISS, S., DEBS, P., NOBEN-TRAUTH, N., and BLANKENSTEIN, T. (2001). Generation of tumor-associated cytotoxic $\mathrm{T}$ lymphocytes requires interleukin 4 from $\mathrm{CD}^{+}{ }^{+} \mathrm{T}$ cells. J. Exp. Med. 194, 1767-1775.

25. CARVALHO, L.H., SANO, G., HAFALLA, J.C., MORROT, A., CUROTTO DE LAFAILLE, M.A., and ZAVALA, F. (2002). IL4-secreting $\mathrm{CD}^{+}{ }^{+} \mathrm{T}$ cells are crucial to the development of $\mathrm{CD} 8^{+}$ T-cell responses against malaria liver stages. Nat. Med. 8, 166-170.

Address reprint requests or correspondence to: Dr. Mauricio M. Rodrigues UNIFESP-Escola Paulista de Medicina Rua Botucatu, 862, 6th floor

São Paulo, SP

Brazil 04023-062

Tel/Fax: (55) (11) 5571-1095 E-mail: mrodrigues@ecb.epmbr

Received 19 July 2002/Accepted 11 September 2002 